\title{
REFORMING THE EUROPEAN UNION JUDICIAL SYSTEM: SIMPLICITY OR COMPLEXITY ${ }^{* *}$
}

\begin{abstract}
With the entry into force of the Lisbon Treaty, the judicial system of the European Union sustained significant reforms. First of all, the European Court of Justice was renamed the Court of Justice of the European Union (CJEU). Further, under the Lisbon Treaty, the CJEU is comprised of the Court of Justice (CJ) and the General Court (GC). The EU Civil Service Tribunal (CST) was a specilized court which operated within the CJE framework until 1st September 2016, when it ceased to exist. Hence, the Lisbon Treaty terminology itself is confusing. Originally set as a three-tier judicial structure, it may be said that the Court today functions as a one-layer structure with two courts. Changes have also been introduced in terms of the Court Statute, Rules of Procedure, Advocates-General, appointment of judges, the number of judges in the General Court, etc.These changes raised tensions, first between the Court of Justice and the General Court, and thenbetween the Court of Justice and the European Parliament, as well as disagreement with the Council's position. On the other hand, the General Court introduced important reforms thatled to an impressive rise inthe number of cases closed andreduced length of proceedings. This paper provides a critical review of these reforms, as it is difficult to assess the short-term and long-term implications. Inthe conclusion, several lessons and recommendations are given in order to improve the efficiency and effectiveness of the Court's work.
\end{abstract}

Keywords: Court of Justice of the EU, General Court, reforms, Lisbon Treaty.

\footnotetext{
* ivica.josifovik@ugd.edu.mk

** This paper was presented at the International Scientific Conference "Law in the context of addressing the Challenges of the Contemporary World", held at the Faculty of Law, University of Niš, on $13^{\text {th }}-14^{\text {th }}$ April 2018.
} 


\section{Introduction}

The Lisbon Treaty introduced significant changes in the EU's judicial system. ${ }^{1}$ In 2011, the Court of Justice of the European Union (CJEU) ${ }^{2}$ submitted its first legislative initiative and, after four years of negotiations, what was adopted at the end was somewhat similar to what was proposed at the beginning. Regulation $2015 / 2422$ changed the judicial system from three layers into one with only two courts (European Parliament, Council, 2015). The possibility of creating specialized courts according the Lisbon Treaty was abandoned. The equality of member-states in appointing judges become crucial to the system: the process of independent nomination of judges was also abandoned. In order to achieve this, the number of judges in the General Court (GC) wasdoubled, without providing additional resources for the personnel and with possibility to be reduced. All these changes were envisaged without any analysis of the long-term implications for any of the institution involved in the legislation process.

The debate surrounding this legislation process caused tensions among EU institutions, first between the Court of Justice (CJ) and the General Court (GC) regarding the meaning of the reform and the way it was proposed by the CJ. Tensions also arose between the CJ and the European Parliament (EP), asthere were some contradictions concerning the Council's position. At first, doubting the need of any increase in the number of judges, the member-states approved the proposal when the need of increase became less obvious. The EP adopted the reform without taking into consideration some of the warnings in the legislation process, such as the impact assessment or serious analysis of the costs and benefits from the offered solutions. Nor such constitutional change drew attention of national parliaments.At the end, numerous legal uncertainties emerged. In the meantime, the GC implemented important reforms that led to a progressive increase of the number of cases closed. The backlog started to disappear in 2014 and dropped drastically in 2015, as well as the length of procedures. ${ }^{3}$ In any case, the "urgency" recognized by the EU institutions and member-states when they approved the double number of judges in 2015 quickly disappeared the same year.

1 Consolidated versions of the Treaty on European Union and the Treaty on the Functioning of the European Union, OJ C 202/1, 07 June 2016.

2 Article 19 of the Treaty on European Union (TEU) provides that the CJEU - the Institution includes various jurisdictions: the Court of Justice (CJ), the GeneralCourt(GC) and specialised courts.

3 The number of applications was 617 in 2012, 790 in 2013, 912 in 2014, and 831 in 2015. The number ofclosed cases was 688 in 2012, 702 in 2013, 814 in 2014, and 987 in 2015. The average length of proceedings fell from 26,9 months in 2013 to 23,4 months in 2014 and to 20,6 in 2015. 
It is difficult to assess the long-term implications. There is no precedent in the EU history, since there was no comparable legislation procedure in the EU's judicial system. Also, there is no precedent in member-states, as no Supreme Court was given the right to legislative initiative. Article 281 of the Treaty on Functioning of the European Union (TFEU) anticipates that the EP and the Council, acting in accordance with the ordinary legislative procedure, may amend the provisions of the Statute, with some exceptions. They may do this either at the request of the CJ and after consultation with the European Commission (EC), or on a proposal from the EC and after consultation with the CJ. The Court had this opportunity according to Article 245 of the Treaty of Nice and Article 188 of the Treaty of Maastricht. Still, according to this procedure, the Statute could only be changed under the same rules necessary for changing the Treaties. Therefore, the EP was not included and member-states acted unanimously. After the Lisbon Treaty, the EP is included in theStatute revision as in any other legislative procedure and the Council may act only with qualified majority. Further, according to the procedure from Maastricht and Nice, all member-states could file amendments but, with the Lisbon Treaty, the CJEU and the EC have a monopoly over the right of initiative.

The Lisbon Treaty also strengthens the three-layer judicial structure of the EU. While the Treaty of Nice evoked the possibility of creating specialized chambers attached to the GC, the Lisbon Treaty anticipates the creation of specialized courts. There were many reasons for this step, as specialized courts were considered to provide greater productivity, fewer expenses, more focused system in the appointment of judges and greater coherence in jurisprudence. The only specialized court is the Civil Service Tribunal (CST), established in 2004 (Council Decision, 2004).

\section{The CJEU Legislative Proposals}

On 28 March 2011, the CJ submitted to the Council and the EP amendments to the Statute of the Court. ${ }^{4}$ The amendments concerned all three courts and were aimed at modifying the rules regarding the Grand Chamber composition and establishing the office of vice-president; providing the possibility to attach temporary judges to specialized courts in order to replace those judges who may be absent for a longer period; and supplementing the GC with 12 new judges. The paper focuses on the proposal for increasingthe number of judges in the GC.

4 Interinstitutional file 2011/0901 (COD), Reform of the Statute of the Court of Justice of the European Union,http://register.consilium.europa.eu/doc/srv?l=EN\&f=ST\%2017657\%20 2011\%20INIT. 
The reasons for the proposal are explained in the explanatory note (Council Document, 2011).For several years the number of cases closed by the GC was lower than the cases submitted. This created increase in its backlog, as well as increase in the length of proceedings. Such development threatened the right of parties to a fair trial, thus violating Article 6, paragraph 1 of the European Convention on Human Rights (ECHR) and Article 47 of the EU Charter of Fundamental Rights.The increase in the GC's workload is relatedtoitsmore extensive jurisdiction after enlargements, as well as the increase in the number of EU legislative acts.

It was considered that the number of cases would increase in future. The undertaken measures and the creation of the CST did not significantly contribute to reducing the GC backlog.Therefore, it was necessary to take one of the two possible approaches offered in the Treaties: either to apply Article 257 of the TFEU and introduce a new specialized court, or to increase the number of judges in the GC according to Article 19 of the TEU. The CJ considered that the second solution was more acceptable in terms of effectiveness, flexibility and consistency.

Regardingeffectiveness, the $\mathrm{CJ}$ indicated that the elimination of the GC backlog would not ease the burden of the GC, as the most complex cases may end up in front of the GC. Moreover, the GC will be required to consider the increased number of appeals against the specialized court decisions, not to mention the possibility to rule on preliminary ruling procedure in the area of intellectual property. Also, it confirmed that it would be easier to integrate new judges in the existing structure, rather than create a new one. Thus, the appointment of new judges would be a faster solution and, therefore, a more appropriate response to the urgency of the situation. Regarding flexibility, the CJ emphasized that it would be more difficult to dissolve a new court after it became operational than to reduce the number of judges. Regarding consistency of the EU law, the CJ also emphasized that every additional creation of specialized court would imply transfer of preliminary ruling procedures in front of the GC as indicated in Article 256, paragraph 3, of the TFEU.

The $\mathrm{CJ}$ considered that additional 12 judges to the GC are necessary. This increase would allow the Court to absorb its backlog and ease the organization of its work giving priority to complex cases and introduction of specialized chambers. The Court did not provide information on how it came to the conclusion that 12 judges were the required figure.

The EC adopted its Opinion on 30 September 2011, completely supporting the CJ's proposal (European Commission, 2011).Regarding the GC amendments, the EC considered that the increasing of number of judges at that moment was not the best solution, while the creation of a new specialized court would give results 
after some period of time. The EC also added that additional amendments to the Statute are necessary, especially some form of specialization in chambers in order to avoid fragmentation; therefore, it proposed the creation of at least two specialized chambers. As the EC is the most attacked institution in front of the $\mathrm{GC}$, the content of its legislative proposal in this area requires serious analysis.

Further, the EC indicated the need to determine arrangements for the nomination of 12 new judges, and emphasized the fundamental goals: to ensure that most appropriate and qualified candidates are nominated; to guarantee stability by requiring member-states to renew the mandate of efficient judges; and finally, to ensure fair representation of all national legal systems. Recognizing that the achievement of these goals is far from being easy, particularly in terms of increasing the number of judges from 28 to 40 judges and the replacement of around 20 judges every three years, the EC proposed two possible models. The first model was to secure equality and stability among member-states. The second model was aimed at finding a balance among the representation of national systems and specialization in certain issues. For this purpose, half of the judges would be appointed according to their specialization in certain area. Both proposals are quite complex.

The legislative procedure in front of the EP was divided in two parts in order to have progress in those elements which are not connected to the composition of the GC.On 5 March 2013, the EP presented its Draft Report proposing that the GC should consist of one judge per member-state, whereas 12 new judges will be designated to serve in the GC, irrespective of their nationality and exclusively on the basis of their professional and personal qualifications, provided that there are no more than two judges per member-state (European Parliament, 2013).The amendments to the Statute of the EU Court of Justice provided that all memberstates may submit nominations and that judges whose mandate expires may also submit applications for nomination. It also provided that a panel, envisaged in Article 255 of the TFEU, shall evaluate candidates and a list of at least half of the judges to be appointed according to the common accord of the member-states.

On 12 December 2013, the EP adopted the amendments in its first reading. However, the rapporteur suggested the voting on the draft-legislation to be postponed in compliance with Rule 52, paragraph 2 of the EP Rules of Procedure, ${ }^{5}$ which applies when the Council additionally modifies the legislation proposal.As the EP agreed, the proposal was returned to the Review Committee in charge. In the first reading, the Council and the EP did not reach an agreement; so, on 15

5 http://europam.eu/data/mechanisms/COI/COI\%20Laws/European\%20Commission/ European\%20Commission_Rules\%20of\%20Procedure\%20for\%20MPs_2013.pdf; In the latest Rules of Procedure this rule is deleted. 
April 2014, the EP finally agreed on the legislative solutionproposed in the first reading of the text adopted on 12 December $2013 .{ }^{6}$

According to the Council document of 15 October 2012, member-states had no agreement on the number of judges to be appointed for reducingthe backlog, the duration of procedures and budgetary implications for any of the options (Council of the EU, 2012).First, the CJ statistical data confirmed that there was an increased gap between the number of new cases in front of the GC and the number of closed cases, and that the GC is not able to handlethe cases in the timeframe determined by internal timetable and deadlines. Second, the document presented calculations without identifying any reliable sources; it was intended to provide a rough assessment on the impact of the increase in the number of judges of the GC, their results and average duration of procedures. Third, costs were estimated for each of these hypotheses.Finally, delays due to lengthy procedures were an obstacle to undertake efficient strategic planning.

A compromise was proposed at the Council's General Affairs meeting in December 2014,involving the appointment of additional nine judges, with a designation system based on two parallel rotation systems. ${ }^{7}$ The top six member-states would appoint four additional judges, each judge to be appointed for two consecutive mandates, while all other member-states would appoint five additional judges, each judge to be appointed for a single mandate. Yet, this proposal was not supported and the discussion continued after the adoption of the new GC Rules of Procedure in April 2015. ${ }^{8}$

On 13 October 2014, the CJ send a letter to the Council proposing to increase the number of judges in the GC to two per member-state, whichwould be done in stages and parallel to the increase of new cases (Court of Justice of the EU, 2011). The letter alsohighlighted the difficulties in appointing new judges to the CST, hence proposing first instance appeals against EU officials to be transferred to the GC andthe dissolution of the CST. Then, the letter set three implementation phases, of which two are completed. The first phase ended in 2015,followingthe appointment of 12 new judges; the second phase ended in 2016 with the appointment of 7 new judges, while the third phase should end in 2019 with the appointment of 9 new judges, which makes a total of 56 judges in the GC.

The letter lists the reasons in four sections. The first section explains the reforms as structural and sustainable. The second section refers to the alternative op-

6 https://eur-lex.europa.eu/legal-content/EN/TXT/PDF/?uri=CELEX:52014AP0358\&fro $\mathrm{m}=\mathrm{EN}$

7 Council's General Affairs Meeting in December 2014, http://www.consilium.europa.eu/ ueDocs/cms_Data/docs/pressData/EN/genaff/134235.pdf

8 Rules of Procedure of the General Court, OJ L 105/1, 23 April 2015. 
tion for creation of specialized courts.The third section adds that this solution eliminates the alleged issue specific to the CST concerning the need to appoint new judges on the basis of merit and not according geographical origin. The fourth section specifies the costs of the proposed reform.

The letter itself did not go without controversy. Some considered it a new proposal, others a revised proposal.Such uncertainty is difficult to accept, especially if it has constitutional consequences. Also, there were concerns in the EP that this new approach has never been submitted to national parliaments. The lack of formality of the special legislative procedure, especially if it refers to quasiconstitutional proceedings, can only be downgraded.

\section{Institutional Debates}

The Council document of October 2014, titled "Reform of the General Court of the European Union - Way forward",indicated the proposals of the CJ (Council of the EU, 2014). Although there was support for the proposal, further work was necessary for the legal guarantees on all three levels of the reform, for budgetary implications and the effects of the reform on the CJ.Some member-states insisted that the three phases be clearly set in legally-binding text that would also verify the mechanism for integration of the CST and that there should be no more than two judges per member-state (of the same nationality) in the CST and the GC. In fact, there was no legal coordination in the Council between the increase of judges and the dissolution of the CST, although both issues are related.

Regarding budgetary implications, the Council outlined the costs. It indicated that the proposal would allow more cases to be assigned to chambers of five judges or the Grand Chamber, as well as the appointment of some judges as Advocates General in some cases, thereby increasing the quality of judgments. All these elements were anticipated without conducting any assessment or consultation with the GC. Such justification has nothing to do with budgetary considerations and without some precise explanation, the reform started to face quite different questions from those necessary to solve the GC's backlog issue. Ironically, the first consequence of some of the proposed measures was to increase the duration of proceedings, which is completely contrary to the main goal of the reform.

Further, the possibility of reducing the cabinet's personnel during the third phase of the reform started to draw some attention, thus implying that additional administrative costs are not needed. In order to respond to the doubts of some member-states whether the suggested increase is the most effective option, the Council repeated its intention to reduce the number of legal secretaries and assistants, thus reducing the expenses by $25 \%$. This statement reveals that the 
key target of the member-states was the appointment of more judges, regardless of the costs and contrary to the GC's efficiency.

These adjustments completely risk the influence of the reform because of absence of managerial and administrative logic. Reducing the number of personnel along with increasingthe number of judges may have negative consequences on productivity, which is evidence of the fact that the GC in 2014 explicitly requested for more personnel instead of judges, as an issue of priority in handling the huge backlog.

On the third aspect, the Council pointed out that the Court would be able to handlethe increased number of appeals on short-term basis and that the Court may be invited to submit reports in 2019 in order to propose necessary appropriate measures. Doubling the number of GC judges and the dissolution of the CST inevitably leads to an increase in the number of appeals in front of the CJ. On this issue, the Council's representatives indicated that a filtering mechanism is needed, but without indicating how to do it in long-term. This is an important feature of the EU's judicial system, which can transform the appeal from an instrument that serves the applicant's interest into an instrument that serves only the Court's legal concerns (Woude, 2014: 3).

The Council stated its position in the first reading in June 2015, anticipating that the Court should publish annual reports and that assessment should be made after each phase of the reform, at the same time confirming that in any case the number of judges should remain two per member-state (Council of the EU, 2015). The draft was adopted after the first reading without additional amendments.

The debate in the EP was much more difficult than the one in the Council. The stakes were higher: additional 28 judges to the GC, and dissolution of the CST, as well as the level of resources. The constitutional influence of the reform was also essential: creating a two-layer instead of a three-layer judicial system, and abandoning the system of independent appointment of judges.

The EP analysis was presented on 17 June 2015, when the Council adopted the proposal in the first reading. According to the analysis, which was quite critical of the proposal, the productivity of the GC significantly increased in the last years, as well as the decrease of the backlog, without a single additional judge. Despite such positive results, the analysis required that the need foradditional 28 judges and the dissolution of the CST should be seriously considered. The facts showed that there was no need for urgent reform of the GC. This absence of urgency gave the legislator time and space in which it would be able to reflect on the nature and structure of the judicial system. ${ }^{9}$

9 Allemano, A., Laurent, P., (2015). Where do we stand on the reform of the EU's Court System? On a reform as shortsighted as the attempts to force through its adoption, EU Law Analysis, 23 
Most of the consequences of the proposal were not completely explained. For example, the $\mathrm{CJ}$ emphasized that the reform is dependable on the dissolution of the CST, but details of such proposal were not submitted to the EP. The CJ indicated that its proposal would lead to restrictions on the right to appeal without providing details of what exactly it had in mind. Therefore, the Court justified its plans for transfer of jurisdiction to the GC,without providing any details. Thus, the EP was excluded from assessing the CJ proposal.

Regarding the GC's request on additional resources for addressing any encountered difficulties, the experience showed that the targeted increase of personnel (legal secretaries, registry personnel and translation service) gives better results, is cheaper and reversible, unlike the dissolution of the CST and the appointment of 28 far more expensive judges. Moreover, with the absence of every assessment of the proposal, it is difficult to understand how the doubling of the number of judges will not reduce (rather than improve) its efficiency and productivity.

In reality, the $\mathrm{CJ}$ was asking the EP to take a big step in the dark by adopting measures that are expensive, radical and irreversible without giving any clear direction as to the consequences. Simple declarations about the increase of the number of cases filed or delays in duration of proceedings are not substitutes for fact-supported and careful analysis. This is even more so with the appointment of new 28 judges and their cabinets, each costing 1 million Euros per year; in the absence of clear, objective justification; it is nothing more and nothing less than mismanagement of public spending.

The EP was aware of technical and budgetary advantages of specialized courts. In its Resolution from 29 April 2015 on discharge of the CJ's budget for 2013, the EPpointed out out that "in 2013, the Civil Service Tribunal completed 184 cases, as against 121 in 2012 (i.e. an increase of $52 \%$ ), thus reducing the number of pending cases by 24 (i.e. a decrease of its backlog by $11 \%$ ); believes that the elimination of the Civil Service Tribunal is an inadequate solution to face the Council's long lasting blockage" (European Parliament, 2015). Additionally, in its amendments, the EP suggested re-introducing numerous features from the process of appointing judges to the CST in the appointment process for the GC. However, the EP adopted the CJ's proposal without any amendments, thus completely going in the opposite direction, following the Council and the EC.

September 2015,https:// verfassungsblog.de/where-do-we-stand-on-the-reform-of-the-euscourt-system-on-a-reform-as-short-sighted-as-the-attempts-to-force-through-its-adoption/ 


\subsection{Differencesbetween the CJ and the GC}

Even in 2015, there was no clear vision of the extent of the backlog, since the two concerned courts (the CJ, the author of the legislative proposal, and the GC, subject of the proposal) presented different analyses. This situation is a direct consequence of the absence of serious analysis of the reasons for the backlog. In fact, four significant changes contributed to the improvement of the overall situation: introduction of a serious system for productivity control;employment of 9 legal secretaries; improvement of stability in its composition; and creation of an advisory panel for the appointment of judges according to Article 255 TFEU.

During the legislative procedure, a surprising development was the deep and growing disagreement between the $\mathrm{CJ}$ and the $\mathrm{GC}$ regarding the actual state of affairs concerning the backlog. The $\mathrm{CJ}$ requested that the number of judges be doubled, without taking into consideration the expressed needs of the GC. In the meantime, the GC adopted internal measures and requested to demonstrate its efficiency. Shortly, for the CJ, the situation in the GC was catastrophic, while the GC considered that it significantly improved.

This steams from the differences in the methodology of both courts. On the one hand, the $\mathrm{CJ}$ has taken into account all possible delays, not only those during the handling of the case by GC's judges and their cabinets. According the CJ, the deadline of two months given to the parties in which they should respond to the question set by the GC, also constitutes time taken by the GC to close the case. If parties request additional period for filing an application due to holidays, this delay is also included in the GC consideration. The GC is also responsible for the time during which the case is suspended, awaiting a judgment from the $\mathrm{CJ}$ in a connected case. The time necessary to review or translate a draft-judgment is also added to the time necessary for the GC to rule on the issue. However, since neither the judges nor their cabinets can do anything about this kind of backlog, the increase in the number of judges is not the adequate solution to solve these issues.

On the other hand, the reports on the GC show significant improvement in the time needed to finish cases and in the number of cases pending. Before the doubling the number of judges, the GC closed more than 1000 cases, with a decrease of 160 pending cases and with a large decrease in the number of old cases. Also, the duration of proceedings determined by judgment was reduced to 10 months.${ }^{10}$ Hence, all other institutions seem to have been obliged to see new reasons for justification of the proposal for doubling the number of judges

10 Compare: https://curia.europa.eu/jcms/upload/docs/application/pdf/2016-10/ qdaq16001enn.pdf, p.17 and https://curia.europa.eu/jcms/upload/docs/application/ pdf/2015-04/en_ecj_annual_report_2014_pr1.pdf, 190. 
in the GC (transfer of competences, changes in the chambers from three to five judges, changes in the appeal system), apart from the reasons for reducing the backlog and the duration of procedures.

In fact, the improvement in the GC's situation is considered to be due to several measures: reducing the size of reports from hearings, abolishing the need of translation into all EU languages, possibility to rule on intellectual property cases without hearings, etc. All these measures are not crucial for the whole reduction of the workload or the duration of proceeding. It is therefore necessary to determine the actual reasons for the improvement and eventually to increase the cabinets of GS's judges, to increase the GC's Registry personnel, to change the Rules of Procedure, although progress has been made with the changes from 2015 for simplification and acceleration of procedures through taking judgments without a hearing with the consent of the parties or a judgment delivered by an individual judge.

The doubling of resources in every system is of great challenge. Nothing makes costs bigger than increasing resources. So, the first thing that needs to be done is to assess the global resources available to the GC (judges, legal secretaries, assistants, and Registry personnel). Doubling the GC judges would make it the largest international court in the world. Although there are obvious differences, it is enough to imagine the same solution to be implemented in the EP or the EC. Comparisons can be made with some of the larger first instance national courts, although such analogy is wrong. By definition, the operation of an international court is quite different from the operation of the national court. The heterogeneity in its membership is bigger, just as the instability in its composition for several reasons. Further, in EU courts, members have two functions to perform. They must rule on cases but, doing that, they reflect their national legal orders. An unstable and decentralized court with 56 judges will require a major investment in time and energy in order to protect the coherence of its jurisprudence without prejudice to the equality of legal systems from which the judges come.

The weakness of this reform is that it creates high-level jobs, while concurrently promising decrease of the second and third echelons in the cabinets. Thus, judges are highly paid for performing tasks that can easily, and with fewer costs, be performed by less qualified personnel. Further, judges are the most unstable component in the entire system. The level of multiplication of judicial posts increases the instability of the entire system, while the increase of legal secretaries and the Registry tends to do the opposite. Finally, the creation of a single large GC concentrates all the appeals in the CJ. As a result, this raises questions concerning the workload of the $\mathrm{CJ}$ judges, as well as the decisions of judicial character made by administrators who are officials in the Court's Registry hierarchy. 
It is wrong to believe that both courts are essentially the same. The dichotomy among them tends to increase. This is important to understand since it implies that what is good for one court does not necessarily mean it is good for the other. The CJ basically decides on matters of law. The GC decides the matters to law and facts. Hence, the proceedings in the GC are longer by nature and the cases are more complex. Judgments that describe the facts and decisions, by their nature, are longer than those in which the facts are found elsewhere or do not arise. Internal review and translation of such judgments requires more time.

The modus operandi of the CJ is highly centralised. All cases are considered at the General Meeting and all important cases are sent to the Grand Chamber of 15 judges, which is designed in order to reduce the differences in interpretation of the EU law. In contrast, the GC is decentralized. All applications are sent to chambers of three judges and $95 \%$ remain there, while only $5 \%$ are judged by chambers of five judges. Thus, the risk of differences in interpretation of the law is higher, although the threat decreases with the right of appeal against GC judgments.

This debate was made without detailed analysis of the possibilities offered by the reform. At the beginning, the member-states were prepared to reject the CJ proposal for budgetary reasons, but they radically changed their approach when promised an additional judge. Then, they requested personnel cuts as a budgetary compensation, a consequence that has not been seriously analyzed. It was decided that the GC would get a lot of judges it had not asked for and would suffer a reduction in the less expensive personnel it was asking for. The main political parties in the EP decided to accelerate the adoption of this reform without conducting any assessment on the impact or analysis of costs and benefits in time when the urgency of the matter disappeared since the GC had control over its backlog.

Since the GC's internal reforms drastically reduced the backlog and reduced the duration of proceedings by the end of the 2015, it became clear that the undertaken measures with small increase in the resources ( 9 additional legal secretaries) contributed greatly to resolving the problem of backlog. ${ }^{11}$ The small increase in the personnel required to obtain such a great result shows that major improvements could be achieved through new, more limited and targeted personnel increases. On the contrary, at the beginning of 2016, the existing uncertainty about personnel in cabinets, the appointment of new judges, the need for deep restructuring in organization and greater replacement of existing judges, gives the effect of destabilizing the GC in whole, thereby threatening the excellent results made in the past.

11 Seytre, D.,(2015). Une insulte à l'intelligence, Le Jeudi, 4 November 2015, http://jeudi.lu/ justice-europeenne -une-insulte-a-lintelligence/. 
In the existing context of budget cuts, it is of great importance for the EU and national institutions to seek productive solutions. The GC's development from 2011 to 2015 reflects the benefit of such an approach, but the legislative debate went in different direction.

\section{Future Lessons BULETI}

Over time various goals were set for the GC reform: reducing the backlog, reducing the duration of procedures, larger chambers, coherence in jurisprudence, new appeal regime, transfer of jurisdiction from the CJ to the GC. A clear vision of long-term goals is necessary for these crucial reforms. Any systematic initiative must begin with a reflection on the $\mathrm{CJ}$. The $\mathrm{CJ}$ adopted different approach rather than concentrating on courts under its judicial hierarchy.

In conducting its legislative role, the $\mathrm{CJ}$ sometimes acted under its standards, required by an actor in the legislative procedure. Legislative procedures must respect specific limitations of the Treaties. Ultimately, all documents arising from the CJ needs to be approved by a joint CJ meeting, catalogued in separate register and made available to public.

Official documents related to any legislative procedure should be adopted by a separate division of the institution. Independent decisions of the CJ President are not in accordance with such standards. Further, the use of undated, unregistered and non-signed $\mathrm{CJ}$ documents in the course of the legislative procedure should be prohibited. It is not possible to justify a legislative reform of constitutional consequences based on documents which no one wants to take responsibility for. Finally, the Treaty should give authority to the institution as a whole (rather than a single court only) to present a legislative proposal.

Consultation among interested parties has become a standard characteristic of all legislative procedures. This is especially the case when proposals have a structural or even quasi-constitutional character. The CJ should apply the same principle when implementing its legislative initiatives.

Regarding the long and controversial process, a serious reference to Article 281 of the TFEU is necessary.The best solution would be simply to abolish the CJ's legislative initiative. The Court should be able to present requests for legislation amendments in limited areas in question, but the EC would be responsible for taking them and then promoting what emerged as its proposal. If this best option is not adopted in the future, the second best option would impose serious procedural limitations on all CJ's legislative initiatives. In particular, this competence must be attributed to the institution as a whole, and not to one of the courts. Further, a clear separation within the institution should be established among 
judicial decisions and administrative or legislative decisions, with a possibility for proper judicial review of the latter. Otherwise, the institution can find itself in a serious mess in ruling on applications regarding legislative acts sponsored and promoted by the $\mathrm{CJ}$.

\section{Conclusions}

The proposal to increase the GC judiciary is the first legislative initiative of the CJ under the Lisbon Treaty, which brought a major shift in the entire judicial system of the EU.

Increasing the number of judges in the GC toa total of 56 judges by 2019 is followed by the dissolution of the CST, thus bringing the three-layer EU judicial system to one or two layers. This has collateral consequences on the appointment process, the geographical basis for recruitment of judges, personnel management, as well as the appeal process.

The member-state's inability to agree on anything, except on simple multiplication of judges, made the situation worse. It made the appointment of judges in specialized courts even more difficult, thereby providing an excuse for their abolition, although they were obviously more quality oriented, more productive and more economical. It has also led to doubling the number of judges in the GC, which had much wider implications. This weakness has clearly become a source of unnecessary spending by the EU.

The reform was made without impact assessment or external consultation. There was nothing resembling the associative process which surrounds the legislative procedures in the EU, especially of quasi-constitutional nature. Also, considerations should be given to the restrictions that apply to the $\mathrm{CJ}$ when initiating legislative proposal.

The position of other institutions during negotiations was surprising. For example, in the first phase, the EC insisted on the need to protect the GC's stability, a point that was forgotten during the second phase. In the first phase, the Council expressed serious doubts about the need to increase the number of judges, while in the third phase when the proposal focused on additional 28 judges, these doubts paradoxically disappeared. Nor has the EP considered the proposal regarding impact assessment or the costs and benefits of the analysis.

Effective rejection of recourse to specialized courts in the EU's judicial system is a fundamental strategic choice. First, it strengthens the member-states role in appointment of judges. The choice of candidates by a committee consisting of specialist is replaced by decision-making by the member-states, a strong intergovernmental reform. Second, in a comprehensivemanner, the reform establishes 
a principle of equal representation of member-states in EU courts. This will have important consequences for the recruitment of EU judges.

The reform is not only related to increasing the number of judges. It also refers to the organization of the GC. The CJ strongly advocated in the Council for some specialization inside the GC, as well as for a system of discretionaryattribution of cases to judges. The member-states and the EC also supported this. However, none of these actors consulted the GC on how the court wants to manage its internal affairs. Therefore, there is a need for further reflection regarding the protection of organizational independence of the EU courts.

Specialization in the GC raises another question in this frame. Unlike the CJ which is very much centralized, the GC functions in a decentralized manner, with chambers of three judges constituting the basic formation in decisionmaking processes. In such frame, the specialization of one judge may have a strong impact on the outcome of the cases. The same could be said about the discretionary attribution of cases. As the CJ and the GC are differently organized, such discretion could have strong impact on the outcome of the procedure. In addition, is such a non-transparent and opaque system for the attribution of cases in line with the ECHR regarding the right to a fair trial?

Finally, the doubling of the GC judiciaryis not in fact a reform, but an example of pure mechanic vision of public service reform. In general, the benefits of such an approach are overrated and the costs are overestimated. Neither the institutions nor the member-states or interested parties considered the functioning of the EU courts;nor did they consider the efficiency and costs of possible reforms. This brought the EU judiciary to a paradoxical situation since all parties followed different approachesin an effort to deal with the budgetary cuts and in search of higher productivity. In the future, all EU institutions must pay more attention to long-term productivity, respecting the quality of justice, recruitment of qualified personnel, productivity of judges, and giving due consideration to public funds.

\section{References}

Allemano, A., Laurent, P., (2015).Where do we stand on the reform of the EU'S Court System? On a reform as shortsighted as the attempts to force through its adoption, EU Law Analysis, 23 September 2015,https://verfassungsblog.de/ where-do-we-stand-on-the-reform-of-the-eus-court-system-on-a-reform-asshort-sighted-as-the-attempts-to-force-through-its-adoption/

Seytre, D.,(2015). Une insulte à l'intelligence, Le Jeudi, 4 November 2015, http:// jeudi.lu/justice-europeenne-une-insulte-a-lintelligence/ 
Woude (van der), M. (2014). In favourof effective judicial protection: A reminder of the 1988 objectives, Revue Concurrences No. 4, 2014.

Legal documents

Consolidated versions of the Treaty on European Union and the Treaty on the Functioning of the European Union, OJ C 202/1, 07 June 2016.

Council of the EU, Council Decision 2004/752/EC of 2 November 2004 establishing the European Union Civil Service Tribunal,OJ L 333/7,9 November 2004.

Council of the EU, Council Document 8787/11, Draft amendments to the Statute of the Court of Justice of the European Union and to Annex I thereto, Brussels, 7 April 2011, http://data.consilium.europa.eu/doc/document/ST-8787-2011-INIT/ en/pdf

Council of the European Union, Position of the Council at first reading in view of the adoption of a Regulation of the European Parliament and of the Council amending Protocol No 3 on the Statute of the Court of Justice of the European Union, Doc. 9375/15, Brussels 12 June 2015.

Council of the European Union, Reform of the General Court of the European Union - Way forward, Doc. 16217/14,Brussels 8 December 2014.

Council of the European Union, Reform of the General Court, 14916/12,Brussels 15 October 2012, http://www.statewatch.org/news/2012/oct/eu-council-reform-ecj-14916-12.pdf

Council of EU, Press Release, 3210th Council meeting General Affairs, Brussels, 11 December 2012http://www.consilium.europa.eu/ueDocs/cms_Data/docs/ pressData/EN/genaff/134235.pdf

Court of Justice of the EU, Response to the invitation from the Italian Presidency of the Council to present new proposals in order tofacilitate the task of securing agreement within the Council on the procedures for increasing the number ofJudges at the General CourtBrussels, 13 October 2014, http://data.consilium.europa.eu/ doc/document/ST-14448-2014-REV-1/en/pdf

European Commission, Commission Opinion on the requests for the amendment of the Statute of the Court of Justice of the European Union, presented by the Court, Brussels, 30 September 2011, https://eur-lex.europa.eu/legal-content/EN/TXT/ PDF/?uri=CELEX:52011D C0596\&from=EN

European Parliament, Committee on Legal Affairs, Draft Report on the draft regulation of the European Parliament and of the Council amending the Protocol on the Statute of the Court of Justice of the European Union by increasing the number 
of Judges at the General Court, 5 March 2013, http://www.europarl.europa.eu/ meetdocs/2009_2014/documents/juri/pr/925/925895/925895en.pdf

European Parliament, Council of the EU, Regulation 2015/2422 of the European Parliament and of the Council of 16 December 2015 amending Protocol No 3 on the Statute of the Court of Justice of the European Union, OJ L 341, 24 December 2015.

European Parliament, Resolution of 29 April 2015 with observations forming an integral part of the decision on discharge in respect of the implementation of the general budget of the European Union for the financial year 2013, Section IV - Court of Justice, OJ L 255/118, 30 September 2015.

Interinstitutional file 2011/0901 (COD), Reform of the Statute of the Court of Justice of the European Union,http://register.consilium.europa.eu/doc/ srv?l=EN\&f=ST\%2017657\%20201 1\%20INIT

Rules of Procedure of the General Court, OJ L 105/1, 23 April 2015;

http://europam.eu/data/mechanisms/COI/COI\%20Laws/European\%20Commission/European\%20Commission_Rules\%20of\%20Procedure $\% 20$ for $\% 20$ MPs_2013.pdf;

https://eur-lex.europa.eu/legal-content/EN/TXT/PDF/?uri=CELEX:52014AP0 $358 \&$ from $=\mathrm{EN}$

https://curia.europa.eu/jcms/upload/docs/application/pdf/2016-10/ qdaq16001enn.pdf

https://curia.europa.eu/jcms/upload/docs/application/pdf/201504/en_ecj_ annual_report_2014_pr1.pdf. 


\title{
Др Ивица Јосифовић,
}

Ванредни професор Правног факултета

Универзитет Гоце Делчев -Штип

Македонија

\section{РЕФОРМА ПРАВОСУДНОГ СИСТЕМА ЕВРОПСКЕ УНИЈЕ: једноставност или сложеност?}

\begin{abstract}
Резиме
Ступањем на снагу Лисабонског уговора, правосудни систем Европске уније претрпео је значајне промене. Пре свега, Европски суд правде је преименован у Суд правде Европске уније (СПЕУ). Према одредбама Лисабонског уговора, Суд правде Европске уније се састоји од Суда правде и Опшег суда. Службенички суд Европске уније, који је функционисао као специјализовани суд у оквиру Суда Правде, престао је да постоји 1. септембра 2016. године. До забуне долази и због саме терминологије Лисабонског уговора. Наиме, иако је првобитно осмишљен као правосудна институција која је обухватала три нивоа (судске инстанце), Суд правде ЕУ данас обухвата два суда. Остале измене односе се на Статут Суда, Пословник о раду, Генералног адвоката Суда, именовање судија, број судија Општег суда (2 судије по држави чланищи од 2019. године). итд.

Ове промене су изазвале тензије, пре свега у односима између Суда правде и Општег суда, затим између Суда правде ЕУ и Европског парламента, као и неслагања са ставом Савета. С друге стране, Општи суд је спровео значајне реформе које су довеле до импресивног повећања броја решених предмета и скраћења дужине поступка. Овај рад даје критички прегледа реформе правосудног система ЕУ, јер је тешко проценити краткорочне и дугорочне импликације оваквог решења. У закључку, аутор даје неколико сугестија и препорука како би се побољшала ефикасност и ефективност рада Суда.
\end{abstract}

Кључне речи: Суд правде, Општи суд, реформа правосуђа ЕУ, Лисабонски уговор. 